\section{REFERENCES}

1. Wedzicha JA, Seemungal TAR. COPD exacerbations: defining their cause and prevention. Lancet 2007;370:786-96.

2. Seemungal TAR, Donaldson GC, Paul EA, et al. Effect of exacerbation on quality of life in patients with chronic obstructive pulmonary disease. Am J Respir Crit Care Med 1998;151:1418-22.

3. Soler-Cataluna JJ, Martinez-Garcia MA, Roman Sanchez P, et al. Severe acute exacerbations and mortality in patients with chronic obstructive pulmonary disease. Thorax 2005;60:925-31.

4. Donaldson GC, Seemungal TAR, Bhowmik A, et al. The relationship between exacerbation frequency and lung function decline in chronic obstructive pulmonary disease. Thorax 2002:57:847-52.

5. Davies L, Angus RM, Calverley PMA. Oral corticosteroids in patients admitted to hospital with exacerbations of chronnic obstructive pulmonary disease: a prospective randomised controlled trial. Lancet 1999;354:456-60.

6. Niewoehner DE, Erbland ML, Deupree RH, et al. Effect of systemic glucocorticoids on exacerbations of chronic obstuctive pulmonary disease. N Engl J Med 1999:340:1941-7.

7. Anthonisen NR, Manfreda J, Warren CP, et al. Antibiotic therapy in exacerbations of chronic obstructive pulmonary disease. Ann Intern Med 1987:106:196-204.

8. Sachs AP, Koeter GH, Groenier KH, et al. Changes in symptoms, peak expiratory flow, and sputum flora during treatment with antibiotics of exacerbations in patients with chronic obstructive pulmonary disease in general practice. Thorax 1995:50:758-63.
9. Monso E, Ruiz J, Rosell A, et al. Bacterial infection in chronic obstructive airways disease: a study of stable and exacerbated patients using the protected specimen brush. Am J Respir Crit Care Med 1995;152:1316-20.

10. Sethi S, Evans N, Grant BJ, et al. New strains of bacteria and exacerbations of chronic obstructive pulmonary disease. N Engl J Med 2002;347:465-71.

11. White AJ, Gompertz S, Bayley DL, et al. Resolution of bronchial inflammation is related to bacterial eradication following treatment of exacerbations of chronic bronchitis. Thorax 2003:58:680-5.

12. Hill AT, Campbell EJ, Hill SL, et al. Association between airway bacterial load and markers of airway inflammation in patients with stable chronic bronchitis. Am J Med 2000;109:288-95.

13. Patel IS, Seemungal TAR, Wilks M, et al. Relationship between bacterial colonisation and the frequency, character and severity of COPD exacerbations. Thorax 2002:57:759-64.

14. Wilson R, Jones P, Schaberg $T$, et al, for the MOSAIC Study Group. Antibiotic treatment and factors influencing short and long term outcomes of acute exacerbations of chronic bronchitis. Thorax 2006:61:337-42

15. Roede BM, Bresser P, Bindels PJE, et al. Antibiotic treatment is associated with reduced risk of a subsequent exacerbation in obstructive lung disease: an historical population based cohort. Thorax 2008;63:968-73.

16. Niewoehner DE, Rice K, Cote $\mathrm{C}$, et al. Prevention of exacerbations of chronic obstructive pulmonary disease with tiotropium, a once daily inhaled anticholinergic bronchodilator: a randomised trial. Ann Intern Med 2005;143:317-26.

17. Calverley PM, Anderson JA, Celli B, et al Salmeterol and fluticasone propionate and survival in chronic obstructive pulmonary disease. N Engl J Med 2007; 356:775-89.

18. Seemungal TAR, Harper-Owen $\mathrm{R}$, Bhowmik A, et al. Respiratory viruses, symptoms and inflammatory markers in acute exacerbations and stable chronic obstructive pulmonary disease. Am J Respir Crit Care Med 2001;164:1618-23

19. Wilkinson TMA, Donaldson GC, Hurst JR, et al. Impact of reporting and early therapy on outcome of exacerbations of COPD. Am J Respir Crit Care Med 2004:169:1298-303.

20. Wedzicha JA, Calverley PMA, Seemungal TA, et al, for the INSPIRE Investigators. The prevention of chronic obstructive pulmonary disease exacerbations by salmeterol/fluticasone propionate or tiotropium bromide. Am J Respir Crit Care Med 2008;177:19-26.

21. Sapey $\mathbf{E}$, Stockley RA. COPD exacerbations 2: Aetiology. Thorax 2006;61:250-8.

22. Wilkinson TMA, Hurst JR, Perera WR, et al. Interactions between lower airway bacterial and rhinoviral infection at exacerbations of chronic obstructive pulmonary disease. Chest 2006:129:317-24.

23. Papi A, Bellettato CM, Braccioni F, et al Infections and airway inflammation in chronic obstructive pulmonary disease severe exacerbations. Am J Respir Crit Care Med 2006:173:1114-21.

\title{
Wheezing phenotypes
}

\section{Louis I Landau}

There are increasing reports of excellent data on wheezing phenotypes in early childhood. ${ }^{1}$ Despite some contradictory findings, generally based on differences in definitions used or ages studied, the findings are gradually providing valuable perspectives towards understanding this very common symptom. It is clear that much of respiratory disease throughout life is programmed during fetal life and the early years after birth. The patterns differ between developing and developed countries, apparently related to differences in microbial exposure, diet and exposure to cigarette smoke. ${ }^{23}$ The outcomes are probably mediated through the effects of these agents, timing of these exposures being critical, on airway development and maturation of the immune system. ${ }^{4}$ The airways may be structurally smaller due to abnormalities of the wall size, function of the smooth muscle or increased thickness of the mucosa. Abnormal maturation of the immune

Correspondence to: Dr L I Landau, The University of Western Australia, Crawley, WA 6009, Australia;

Ilandau@meddent.uwa.edu.au system influences the response to both allergens and microbes promoting either hypersensitivity or tolerance. ${ }^{5}$

Cough and wheeze are very common symptoms in the early years of life with more than $60 \%$ coughing and more than $30 \%$ wheezing in the first year. ${ }^{6}$ Wheeze is a cardinal symptom of asthma but, in the first year of life, more than half is likely to be due to causes other than asthma such as congenitally small airways, bronchiolitis, cystic fibrosis, congenital heart disease, aspiration syndromes, social disadvantage and chronic neonatal lung disease

A predisposition to wheeze is seen with small airways related to factors such as male gender and exposure to maternal smoking. ${ }^{7}$ It is more likely at this age due to a lack of collateral ventilation, a weak chest wall with reduced tethering of the airways, increased smooth muscle in the peripheral airways (particularly in preterm infants) and an immature immune system.

There have been many genes associated with asthma prevalence, severity or response to drugs, although no single gene accounts for more than $10 \%$ of the asthma phenotype. ${ }^{8}$ Those identified generally relate to $\beta_{2}$ receptor activity, immune maturation or function and leucotriene metabolism.

Prospective longitudinal studies commencing before birth such as those from Tucson, ${ }^{9}$ Melbourne, ${ }^{10}$ Perth ${ }^{11}$ and Bristo ${ }^{12}$ have been reported; a follow-up from this last study by Henderson and colleagues is included in this issue of Thorax (see page 974). They have defined four or more patterns of preschool wheezing: early transient (first year only), late transient (second or third year), persistent (from first year to beyond 6 years) and late onset (commencing after 3 years). Better information on these phenotypes has been obtained with measurements of lung function in this age group by forced expiratory flows using the rapid thoracic compression technique, ${ }^{13}$ tidal breath analysis, ${ }^{14}$ interrupter resistance measurements, ${ }^{15}$ multiple breath gas washout and lung volumes, ${ }^{16}$ exhaled nitric oxide, ${ }^{17}$ analysis of induced sputum ${ }^{18}$ and airway hyper-responsiveness. ${ }^{19}$

Those with early transient wheezing have been found to have low flow rates and airway hyper-responsiveness before the onset of symptoms associated with male gender and maternal smoking. Other triggers are being sought. One manifestation of this pattern is bronchiolitis in the 
first year where those who develop the clinical syndrome on exposure to the respiratory syncytial virus are more likely to have low lung function present before the onset of the acute illness. Those who develop bronchiolitis in the second year are more likely to be atopic, with more having positive skin prick tests $(57 \%$ vs $22 \%$ ) and to subsequently be diagnosed with asthma (71\% vs $22 \%){ }^{20-22}$ Similarly, those with late transient wheezing have abnormally low maximum expiratory flow but variously reported atopy. Those reported in the paper by Henderson et a ${ }^{12}$ do have increased prevalence of atopy. These inconsistencies probably highlight the problem of categorising continuous variables by age at 1, 2, 3, 4 and 6 years.

Persistent wheeze has been associated with low flows in some prospective studies but not in others. ${ }^{92}$ Low airway responsiveness at both 1 month and 6 years is associated with above average lung function and little probability of asthma, while high airway responsiveness at both 1 month and 6 years is associated with a $50 \%$ chance of developing asthma and below average lung function. Those with low airway responsiveness at 1 month which is high at 6 years have an average risk of developing asthma and average lung function probably reflecting the evolving disease in those with late onset asthma, while those with high airway responsiveness at 1 month which is low at 6 years have an intermediate risk of developing asthma and average lung function. ${ }^{22}$ These observations provide insight into possible processes but are not sufficiently predictive in individuals.

The risk of developing asthma increases with the presence of atopy, parental asthma and increasing number of episodes of preschool wheeze. ${ }^{21}$ It is also increased in those hospitalised with bronchiolitis, ${ }^{24}$ those with recurrent croup $^{25}$ and those with croup and wheeze. ${ }^{23}$

Transient wheeze is more common in children not breast fed, with a greater number of siblings and day care, consistent with increased infections in those with small airways. Persistent wheeze is more common with persistent breast feeding (cause or reverse causation), fewer siblings and no day care. ${ }^{26} 27$

What have we learnt? Preschool wheeze is the result of a complex interaction of genetic and environmental factors starting during fetal life and manifests in the early years of life. The predictors of the causes and the outcomes will vary when assessed clinically, epidemiologically or when researched with multiple objective measurements. We are increasingly recognising an evolving syndrome with better information to inform parents and to seek mechanisms which should lead to opportunities for prevention and/or reversibility. Unfortunately, early steroid therapy-most effective as a preventer of symptoms in established asthma-has been shown not to be effective for this purpose. ${ }^{28}$ Although none of the cohorts has yet been followed through to old age, low lung function does track below average and this group may be at risk for chronic obstructive airway disease much later in life. ${ }^{29}$

Competing interests: None.

Thorax 2008;63:942-943. doi:10.1136/thx.2008.104695

\section{REFERENCES}

1. Stein RJ, Martinez FD. Asthma phenotypes in childhood: lessons from an epidemiological approach. Paediatr Respir Rev 2004;5:155-61.

2. Landau LI. Mini-symposium: smoking from womb to tomb. Paediatr Respir Rev 2008;9:1-44.

3. Landau LI. Paediatric basis of adult lung disease. Paediatr Respir Rev 2006;7 Suppl 1:S251-4.

4. Ball CT, Castro-Rodriguez JA, Griffith KA, et al. Siblings, day care attendance and the risk of asthma and allergy in childhood. N Engl J Med 2000;343:538-43.

5. Prescott SL, King B, Strong TC, et al. The value of perinatal immune responses in predicting allergic disease at 6 years of age. Allergy 2003;58:1187-94

6. Weiss LN. The diagnosing of wheezing in children. Am Fam Physician 2008;77:1109-14.

7. Young S, Sherrill DL, Arnott J, et al. Parental factors affecting respiratory function during the first year of life. Pediatr Pulmonol 2000;29:331-40.

8. Mellis CM, Landau LI. Early childhood asthma. Med J Aust 2002;177(Suppl):S37.

9. Morgan WJ, Stern DA, Sherrill DL, et al. Outcomes of asthma and wheezing in the first 6 years of life. The Group Health Medical Associates. N Engl J Med 2005;172:1253-8.
10. Phelan PD, Robertson CF, Olinsky A. The Melbourne Asthma Study: 1964-1999. J Allergy Clin Immunol 2002;109:189-94.

11. Turner SW, Palmer LJ, Rye PJ, et al. Infants with flow limitation at 4 weeks: outcome at 6 years and 11 years. Am J Respir Crit Care Med 2002;165:1294-8.

12. Henderson J, Granell R, Heron J, et al. Association of wheezing phenotypes in the first 6 years of life with atopy, lung function and airway responsiveness in mid-childhood. Thorax 2008;63:974-80.

13. LeSouef PN, Hughes DM, Landau LI. Shape of forced expiratory flow volume curves in infants. Am Rev Respir Dis 1988;138:590-7.

14. Haland G, Carlsen KH, Devulapali CS, et al. Lung function development in the first 2 years of life is independent of allergic disease by 2 years. Pediatr Allergy Immunol 2007;18:528-34.

15. Brussee JE, Smit HA, Koopman LP, et al. Interruptor resistance and wheezing phenotypes at 4 years of age. Am J Respir Crit Care Med 2004;169:209-13.

16. Gustafsson P. Inert gas washout in preschool children. Paeditr Respir Rev 2005;6:239-45.

17. Brussee JE, Smit AH, Kerkhoff M, et al. Exhaled nitric oxide in 4 year old children with asthma and atopy. Eur Respir J 2005;25:455-61.

18. Simpson JL, Wood LG, Gibson PG. Inflammatory mediators in exhaled breath, induced sputum and saliva. Clin Exp Allergy 2005;35:1180-5.

19. Turner SW, Young S, Landau LI, et al. Reduced lung function before and after bronchiolitis and at 11 years. Arch Dis Child 2002;87:41720.

20. Lodrup Carlsen KC, Carlsen KH, Nafsted P, et al. Perinatal risk factors for recurrent wheeze in early life. Pediatr Allergy Immunol 1999;10:89-95.

21. Castro-Rodriguez JA, Holberg CJ, Wright $A L$, et al. A clinical index to define risk of asthma in young children with recurrent wheezing. Am J Respir Crit Care Med 2000;162:1403-6.

22. Turner SW, Palmer LJ, Rye PJ, et al. The relationship between infant airway function, childhood airway responsiveness and asthma. Am J Respir Crit Care Med 2004;169:921-7.

23. Castro-Rodriguez JA, Holberg CJ, Morgan WJ, et al. Relation of different subtypes of croup before age 3 to wheezing, atopy and pulmonary function during childhood: a prospective study. Pediatrics 2001;107:512-8.

24. Sigurs N. A cohort of children hospitalized with acute RSV bronchiolitis: impact on later respiratory disease. Paediatr Respir Rev 2002;3:177-83.

25. Zach MS, Schnall RP, Landau LI. Upper and lower airway hyper-reactivity in recurrent croup. Am Rev Respir Dis 1980;121:1979-83.

26. Guilbert TW, Stern DA, Morgan WJ, et al. Effect of breast feeding on lung function in childhood and modulation by maternal asthma and atopy. Am J Respir Crit Care Med 2007;176:843-8.

27. Rothers J, Stern DA, Spangenberg A, et al. Influence of early day care exposure on total lgE through 3 years. J Allergy Clin Immunol 2007;120:1201-7.

28. Guilbert TW, Morgan WJ, Zeiger RS, et al. Long term inhaled corticosteroids in preschool children at high risk for asthma. N Engl J Med 2006;354:1985-97.

29. Hibbert ME, Hudson IL, Lanigan A, et al. Tracking of lung function in healthy children and adolescents. Pediatr Pulmonology 1990;8:172-7. 